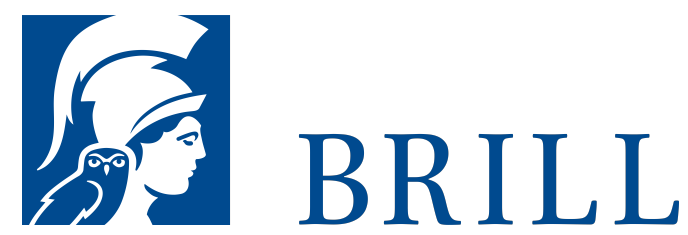

\title{
Der Kreuzzug gegen Mahdiya 1390
}

Konstruktionen eines Ereignisses im spätmittelalterlichen Mediterraneum

Author: Urs Brachthäuser

Die Berichte der Chronisten über den Angriff einer Allianz aus genuesischen Bürgern und französischen Adeligen auf die tunesische Stadt Mahdiya werfen ein Schlaglicht auf die wechselhaften Beziehungen zwischen Europa und Nordafrika im Spätmittelalter.

Im Mittelpunkt stehen der Konflikt zwischen der Seerepublik Genua und Tunis, die Verankerung des damaligen Kriegszuges in der ritterlich-höfischen Kultur der Zeit sowie die Darstellung Nordafrikas und der Muslime. Ein Akzent liegt dabei auf der Kontinuität von Idealen, Deutungen und Traditionen, die mit den Kreuzzügen verbunden sind. So werden auch die Spannungen zwischen chronikalischen Erzählungen und der komplexen historischen Realität sichtbar.

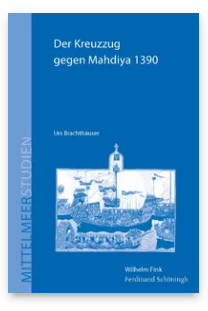

Pages: 822

Seiten

Language:

German

Subjects:

Medieval

History, History

Publisher: Brill |

Schöningh

Series:

Mittelmeerstudien,

Volume: 14

E-Book (PDF)

Released online:

o5 Oct 2021

ISBN: 978-3-

657-78551-3

List price

Hardback

Publication date:

16 Jan 2017

ISBN: 978-3-

506-78551-0

List price 
For more information see brill.com

Order information: Order online at brill.com +44330 333 0049 | customerservices@brill.com Submission information: brill.com/authors

Titles published by Brill | Fink, Brill | mentis or Brill | Schöningh: +49(o)715413279216| brill@brocom.de 